\title{
ТЕМЕЉИ СРПСКЕ ГЕОПОЛИТИЧКЕ ШКОЛЕ
}

Кључне ријечи:

\section{Цвијићева} антропогеографија; српско питане; посибилизам; телурократија; мултидисииплинарност; геополитика.

Аутори:

Др Миломир Степић је редовни професор и научни савјетник на Институту за политичке студије $y$ Београду.

Мр Желько Будимир је виши асистент на Факултету политичких наука Универзитета у Бағоо Луции.

Коресподенција: milomir.stepic@gmail.com zeljko.budimir@fpn.unibl.org

Област:

Геополитика

DOI:

10.5937/politeia0-22110

Датум пријема чланка:

11.04.2019.

Датум прихватања чланка за објављивање:

\section{Сажетак}

Практична геополитика дуго постоји у српској традииији, али се у научном смислу недоволно развила. Прави зачеци српске геополитичке мисли могу се пронаћи у антропогеографским радовима Јована Цвијића током првих деценија 20. века и неговом ангажману приликом формирана јужнословенске државе. Потом је наступио дуг дисконтинуитет, нарочито изражен после Другог светског рата због нацистичке злоупотребе геополитике. Ренесанса и истински развој српске геополитике почео је из егзистениијалних националних разлога - када је дезинтеграцијом Југославије и у неповољним међународни околностима поново отворено српско питане. Од тада су сазреле четири генерације геополитичких стручюака, у чијим истраживағима постоји специфичан заједнички научни приступ, те се може констатовати да настаје аутентична српска геополитичка школа. Њена основна својства јесу та да је посибилистичка, телурократска, интегралистичка, регионалистичка (балканска) и мултидисииплинарана, те да је, заједно са универзалном, успоставила и сопствену терминологију. Дали напредак српске геополитичке школе зависиће од уважавана у политичко-дипломатској пракси, позиције у образовно-научном систему, адекватне медијске промоиије и успешног сузбијана тривијализације. 
УВОД

Геополитика дуго постоји као схватање и чињење усмерено на територијализацију политичких интереса. Континуирано мислити и понашати се геополитички значи имати стратешку културу. Истрајно деловати геополитички значи опстати и развијати се. Али, то није довољно да се геополитика научно артикулише. Геополитика јесте стара пракса, али је релативно млада наука. Њене претече појавиле су се у адекватном историјско-политичком тренутку, када се у другој половини 19. века појавила једна нова, тек уједињена велика централноевропска држава експанзионистичких, империјалних амбиција - Немачка - и када је она у борби за простор постала конкурентна већ постојећим европским силама. Такође, мајка-наука која је изнедрила геополитику доживљавала је развојни врхунац јер је успела у ономе што се до тада махом сматрало „немогућом мисијом“ - да, иако детерминистички, успостави међузависност између људског друштва и природе у просторном контексту. Била је то антропогеографија, из које је изведена политичка географија. Традиционалистики оријентисани географи и данас геополитику сматрају примењеном политичком географијом. Иако су просторни аспекти политичких феномена, логично, са уважавањем прихваћени у војној науци, ипак у њеном окриљу није дошло до артикулисања посебне научне дисциплине или јасно индивидуалисане науке. Трновит научни пут геополитике почео је тек када je Р. Кјелен (Rudolf Kjellén) 1899. године први употребио кованицу геополитика (Kjellén 1899: 283-331), а убрзо потом и Х. Мекиндер (Halford John Mackinder) 1904. године објавио чланак „Географска осо- вина историје“ (Mackinder, 1904: 421-443), који се и данас сматра „главним геополитичким текстом у историји те дисциплине“ (Dugin, 2004: 47) зато што садржи „теорију која ће постати, осовина' око које ће се вртети будућа кретања у геополитици и геостратегији“ (Budimir, 2012: 225).

Људске заједнице, народи и земље су, наравно, и пре званичне појаве геополитике имале своја виђења „опросторења политичког“ (Pavić, 1994: 81), те су у том контексту формирале своје тренутне, краткорочне и дугорочне интересе. Миленијумима траје надметање за простор - од најранијих друштвених формација и првих државних облика, до појаве великих европских сила и актуелних глобалних држава-дивова, али и других чинилаца (субдржавних, наддржавних, недржавних). Водећи „играчи“ међу њима имали су своје доминантне, мејнстрим (main stream) геополитичке приступе, идентитете, формуле за владање сопственим простором, регионалне и глобалне експанзионистичке концепције, те сопствене геополитичке школе. Геополитичке школе моћних држава и наука махом су се темељиле у њиховим исконским сакрално-географским и верско-националним (цивилизацијским) идентитетима, потом су дограђиване империјалним и колонијалним традицијама, да би научно директно проистицале из већ формираних географских, етнографских, историографских, правних, полемолошких, економских и других школа.

Јасно су се издвојиле и данас су препознатљиве следеће важне геополитичке школе:

- немачка, класична, геодетерминистички заснована, иницијално mitteleurop-ски замишљена, потом телурократски уобличена школа, 
коју је поставио географ и генерал К. Хаусхофер (Karl Haushofer);

- франиуска, посибилистичка школа повезана са принципима „geographie humaine“, коју је утемељио П. В. де ла Блаш (Paul Vidal de la Blache), а из које је проистекла савремена регионално-геополитичка и „полит-детерминистичка“ школа И. Лакоста (Yves Lacoste);

- британска, колонијалистичка, на тријалистичком моделу постављена, de facto таласократска школа, чији je оснивач X. Мекиндер (Halford John Mackinder), а која се и данас „храни“ русофобном претњом из евроазијског Heartland-a;

- америчка, из таласократских ставова адмирала А. Т. Мехена (Alfred Thayer Mahan) проистекла, потом на постулатима rimland-изма $\mathrm{H}$. Спајкмена (Nicholas John Spykman) осмишљена, те у време биполаризма и униполаризма (глобализма), доприносом Х. Кисинџера (Henry Alfred Kissinger), 3. Бжежинског (Zbigniew Kazimierz Brzezinski) и других теоретичара и практичара допуњена и конкретизована школа;

- руска, евроазијска, „место-развојна“, идеја о Русији-Евроазији као засебном, трећем континенту, коју је геополитички изразио П. Савицки (Петр Николаевич Савицкий), а реактивирао, осавременио, континенталистички артикулисао и као неоевроазијску школу конституисао А. Дугин (Александр Гельевич Дугин);

- кинеска, у новије време заснована и геоекономијом замаскирана, али несумњиво геополитички устројена интегрална „свилена школа“ (и таласократска и телурократска, и аерократска, и сајбер, и...), коју персонификује председник Си Ђинпинг.

Да ли само велике силе, које испољавају (транс)континенталне и глобалне амбиције, „смеју“ да имају геополитичку традицију која може да се сматра (и) школом? Могу ли да је имају и регионалне силе као што је Турска са својим некада мање, а некада више израженим пантуркизмом, неоосманизмом и/или Давутоглуовом (Ahmet Davutoğlu) „Стратегијском дубином“? Шта ако геополитичка концепција, преточена у школу, није довољно позната и обзнањена, већ може само да се препозна на основу реализације, као што је исламска? Како то оспорити појединим значајним и снажним земљама, у које спада, на пример, Италија са својим неугаслим експанзионистичким амбицијама, геополитички артикулисаним у виду слогана „Spinta verso oriente“ и „Mare nostro Adriatico“? Малим народима и земљама, штавише, доводи се у питање чак и право на геополитичко мишљење, сугерише им се да је за њих геополитика излишна, те да имају само да се прилагођавају моћнима. Сходно томе, довољно је да њихова геополитика буде следбеничка, апологетска, јер оне у светским и регионалним пословима нису субјекти, већ објекти, тј. само су предмет интереса, те да, као такве, не могу да имају сопствене интересе, већ само егзистенцијалне нагоне. 


\section{ПРАПОЧЕЦИ СРПСКОГ ГЕОПОЛИТИЧКОГ МИШЪЕЊА}

Ексклузивистички ставови великих сила, па и њихових наука реалистички су схватљиви и увек су постојали. „Велики“ на „мале“ увек су гледали са ниподаштавањем. Међутим, геополитика за „мале“ није питање пуког просторног пулсирања, владања сопственом или туђом територијом и утицаја на (ре)дефинисање светског система или регионалне конфигурације, већ најчешће питање голог опстанка. Њихова геополитика мора да уважава како историјске константе, глобалне концепције великих сила и правилности у реализацијама конкретних субпоредака, тако и утицај нових геополитичких парадигми, пројекције промена у хијерархији моћи на окружење и преображај локалних „фаворита“ у „аутсајдере“ и обрнуто. Ово се у првом реду односи на народе и државе у осетљивим регионима какав је Балкан, који се може сматрати синонимом геополитике. После Блиског истока, Балкан је, у тзв. процесима дугог трајања, вероватно најважнији геополитички регион на свету. У ствари, они функционишу по принципу „спојених судова“.

Балкан је предмет геополитичког надметања великих сила првенствено због изванредне важности свог положаја, и то не само у оквирима Европе и Евроазије, већ Афро-евроазије (Старог света или, према Мекиндру, Светског острва) и планете у целини. Стога се за Балкан често користе индикативни називи catena mundi, „земља у процепу светова“, „прецизни сеизмограф глобалних потреса“, „буре барута“, „балкански потконтинент“, „балкански геополитички чвор“... Штавише, појам балканизација ушао је у светску литературу и дипломатску праксу, те све више добија универзални карактер када у једној речи треба сажети три појаве/процеса: хетерогеност, фрагментираност и спољашње утицаје. То су разлози из којих балкански чиниоци морају да негују геополитички поглед на свет, да геополитички делују и да геополитички школују своју елиту. То најпре важи за српске земље и народ, који се налазе у средишту Балкана, за које још увек важи чињеница констатована почетком 20. века да „од Беча до Цариграда нема већег народа“" (Cvijić, 1987: 66) и где се вековима укрштају најважнији геополитички вектори. Постоји ли аутентично српско геополитичко учење? Шта је слично, а шта је њена differentia specifica која је одваја од геополитичког поимања суседа, других народа, кључних регионалних и великих сила? Да ли се већ може говорити о српској геополитичкој школи, када је у мирним историјским околностима потребно неколико научних генерација које ће повезивати заједничка мисаона геополитичка „златна нит“?

Бурни догађаји растакања Југославије крајем 20. и почетком 21. века проузроковали су нагло српско геополитичко буђење и убрзано сазревање. Срби су на болан начин схватили да нису своје национално питање затворили стварањем југословенске државе, да су у њој само били заробљени у „златном кавезу“ (Stepić, 2018: 297), да оно није никакво демократско, већ par exelence геополитичко питање (Stepić, 2004). И да се оно мора тако не само схватати већ и решавати. Отрежњење се десило са трагичним закашњењем и неспремношћу. Ипак, појављивало се све више аутора у чијим је научним и публицистичким радовима, књигама, предавањима, јавним излагањима и медијским наступима могао да се 
препозна заједнички приступ каузалности просторног и политичког. Назирали су се обриси српске геополитике, али је било неопходно вратити се извориштима. Упркос недостатку релевантних историјских извора, прапочеци српске (практичне) геополитике могу се препознати у формирању, функционисању, организацији, брањењу, ширењу, трансформисању и позиционирању српске средњовековне државе и цркве. Завидно прагеополитичко знање и умешност показивали су тадашњи српски владари, а задивљујућа способност замонашеног принца и првог српског архиепископа Саве (Растка Немањића) допринела је тадашњој српској самосталности, а потом и успону на трон водеће балканске и једне од респектабилних европских сила. Стога се аргументовано може говорити о „геополитици светосавља“ (Despotović, 2019: 51-53). Историјски ближа, познатија и очигледнија је практична геополитичност у начину васпостављања и обнове државности током 19. века. Писаних протогеополитичких трагова има у тадашњим делима махом историографског и географског („земљописног“) карактера код Јована Рајића ${ }^{1}$, Павла Соларића ${ }^{2}$, Ивана Југовића (Јована Савића) ${ }^{3}$, Јоакима Вујића $^{4}$, Вука Караџића ${ }^{5}$, Јована Гаври-

1 Четворотомна Историја разних словенских народов, најпаче Боглар, Хорватов и Сербов (1794/1795).

2 Двотомно Прво гражданско землеописание, прво на језику србском, са Землеописником од XXXVII листова (1805) садржало је само неколико страница посвећених Србији у оквиру Османске империје.

3 Уџбеник Всеопште гражданско землеописание - Географија Предавања на Великој школи у Београду (1811).

4 Новејше землописаније (1825).

5 Географско-статистичко описаније Србије (1827), Montenegro und die Montenegriner (1837), ловића ${ }^{6}$, Јована Драгашевића ${ }^{7}$, Милана Ђ. Милићевића ${ }^{8}$, Владимира Карића ${ }^{9} .$.

За заснивање српске геополитичке самоспознаје драгоцене су и прве етногеографске карте, које су, упркос не тако безначајним пропустима, не само давале представу о интегралности, обрисима и положају српских земаља већ су и парирале картографској пропаганди великих сила и суседа. Оне су се махом појављивале у саставу наведених књига, али и као посебна издања (листови). Међу њима, свакако би требало апострофирати карте оснивача српске картографије Захарија Стефановића Орфелина из друге половине 18. века. Својим значајем истиче се прва српска карта српских земаља „Земљоображеније Србске, Босне, Далмацје, Дубровне, Црне Горе и ограничних предел“, коју је у сврху афирмације Првог српског устанка објавио Сава Поповић Текелија 1805. године. Вајнгартенова карта у његовом делу Uber Serben из 1820. године садржи прилично прецизан приказ рељефа, хидрографије и саобраћајница, али обилује нетачностима у топонимији, позицији насеља и нарочито административној подели. На основу корекција које је у њој извршио Вук Караџић урађена је и објављена карта као прилог књизи Die Serbische Revolution Леополда Ранкеа 1829. године, а послужила је за одређивање граница Србије после стицања аутономије 1830. године (Živković, 2012: 2-3).

У другој половини 19. века, упоредо

Срби сви и свуда (1849), Бока Которска (1849), Живот и обичаји народа српскога (1867).

6 Речник географијско-статистични Србије (1846), Мали земльопис Кюажевства Сербије и Турског иарства у Европи (1850).

7 Принос за географију Србије (1873).

8 Кнежевина Србија (1876) и Кралевина Србија (1884).

9 Србија-опис земле, народа и државе (1887). 
са назирањем, а потом и остваривањем независности Србије, уследило је објављивање две врсте карата важних не само у информативном, образовном и научном смислу, већ и за визуелизацију територијалних аспеката величине, интегралности, националног идентитета, односа са суседима, па и геополитичког позиционирања целокупног српског чиниоца. Једној групи припадају карте Србије на Балкану, који је са слабљењем Османске империје већ почињао да добија своју политичко-територијалну структуру. Такве су, на пример, „Карта Књажевства Србије“ Јована Бугарског из 1845. године, „Књажевство Србија“ Јована Миленковића из 1850. године, карта Србије за војне потребе мајора Љ. Ивановића из 1869. године, школска „Карта Србије и Црне Горе“ Јована Цвијића из 1897. године и остале. Друга група су етничке карте Балкана или карте размештаја само српског народа и српских земаља, као што су, на пример, „Историјско-етнографска карта Срба“ Милоша Милојевића из 1873. године, „Србија“ Милојка Веселиновића из 1887. године, пет листова „Етнографске карте Старе Србије и Македоније“ Спиридона Гопчевића из 1890. године...

\section{ЗАЧЕЦИ СРПСКЕ НАУЧНЕ ГЕОПОЛИТИКЕ}

Претеча српске политичке географије и геополитике јесте Димитрије Тирол (17931857), који је аутор књиге Политическо землописаније - за употребленије сербске младежи из 1832. године. У њој је географију поделио на „математическу, физическу и политическу“, приказао све тадашње земље света, међу којима и српске под османском окупацијом, те дао основне податке о неколико „вароши“ у Србији.
За тадашњи Београд написао је да има 17.000 становника и да представља „средоточје трговине између Беча и Цариграда" (Stanković, 2012: 6).

Истинским зачетником српске научне геополитике може да се сматра Јован Цвијић. Она је изданак његовог специфичног антропогеографског приступа, који се потом развио у познату српску антропогеографску школу. Цвијић се у напону стваралачке снаге нашао управо приликом формирања погодног „амбијента“ за настанак и развој геополитике: после објављивања Антропогеографије 1882-1891. године и Политичке географије 1897. године Ф. Рацела (Friedrich Ratzel), онда када се немачком геодетерминизму супротставио француски геопосибилизам П. В. де ла Блаша, у време Кјеленовог „кумовања“ геополитици 1899. године и њеног позиционирања као једног од пет субсистема науке о држави у књизи Држава као животни облик 1916. године, упоредо са појавом Мекиндеровог рада „Географска осовина историје“ 1904. године, а потом и његове Heartland-теорије у књизи Демократски идеали и стварност 1919. године... Истовремено, био је то повољан међународно-политички тренутак када су јачали национални покрети и распламсавала се борба за балканско наслеђе „болесника са Босфора“, мењала се политичка карта и границе, расли антагонизми међу великим силама, артикулисали се њихови експанзионистички интереси и успостављали вектори продоpa, а научници се ангажовали као интелектуална логистика у сврху остварења националних циљева.

Са одмицањем научно-наставне каријере, Цвијић се са физичкогеографских истраживања временом све више оријентисао на комплексна антропо- 
географска питања. У његовом рукопису предавања из Onште географије - антропогеографије из 1901. године (накнадно објављен), посебно поглавље назива се „Државе - политичка географија“. Оно се састоји од деветнаест потпоглавља, међу којима већина има очигледне геополитичке наслове и садржину: Присвајање земљишта; Правни облици државе; Класификација држава по величини; Светска царства и колонијална царства; Велике државе; Средње државе; Мале државе (део је посвећен тзв. варошким државама); Политички простор; Географски и политички положај; Растење и облик државних области; Језгра, основне области држава; Поморске силе; Политичке границе; Разгранатост граница; Унутрашња деоба државне области; Границе колонија и интересних сфера; Врсте спољних територија; Развитак спољних политичких територија и Данашње стање (Cvijić, 1969: 47-76).

Како је Балкан постајао све узаврелији, Цвијић, „султан српске науке“ и „дворски географ“, све више се посвећивао „националном раду“. Уследили његови бројни ангажовани јавни наступи, чланци, студије, књиге и етничке карте. Немерљив значај за учвршћивање српског националног, а нарочито геополитичког идентитета, имала су његова проучавања метанастазичких кретања и порекла становништва (насеља српских земаља) која су јасно одређивала обрисе српског простора. Иако није користио појам геополитика, неколико његових радова имало је мање или више наглашену, делимичну или потпуну, експлицитну или мимикријску геополитичност - о позицији и својствима простора између јужне границе тадашње Србије и Солуна ${ }^{10}$, о вишедимензионалној важности „срца“ Балкана ${ }^{11}$, о (дез)интегративном положају „уметнуте земље“ и „политичке земљоузине“ - Новопазарског санџака - који је добио „погрешно, али укорењено име“ (Cvijić, 2000: 119) ${ }^{12}$, о различитим аспектима „македонског проблема“"13, о антисрпским намерама аустроугарске анексије Би $\mathrm{X}^{14}$, о Србији у Првом балканском рату ${ }^{15}$, о маритимној оријентацији Србије преко садашње северне Албаније као оправданој „антиетнографској нужности“16, о територијалном обликовању, државотворном процесу и положају Србије пред Први светски $\operatorname{paT}^{17} \ldots$

Ванредну вредност имају Цвијићеве етничке и друге карте из тога времена, које су махом објављиване као прилози у његовим осталим научним радовима. Међу њима, две су геополитички карактеристичне. Једна се појавила у јеку Првог светског рата као „подлога“ пројекту јужнословенског уједињења, али са уцртаном „Западном границом географске целине у којој преовлађују православни“ (Dinaricus, 1915), мада се она пре може тумачити као могућа унутрашња политичка или административна међа. Друга карта, објављена на крају рата, представља детаљну етничку слику не само Балканског полуострва,

10 „Географски положај Старе Србије и Македоније“ (1904).

11 „ентрална област и балканско територијално језгро“ (1904)

12 „Политички значај Новопазарског санџака“ (1904)

13 „Неколико проматрања о етнографији Македонских Словена“ (1905), „Географске основе македонског питања“ (1916)...

14 „Анексија Босне и Херцеговине и српски проблем“ (1908).

15 „Балкански рат и Србија“ (1912).

16 „Излазак Србије на Јадранско море“ (1913).

17 „Географски и културни положај Србије“ (1914). 
већ и области саверно од Саве и Дунава, тj. читавог геополитичког Балкана (Cvijić, 1918). Било би интересантно упоредити је са актуелном етнопросторном сликом, једно столеће касније, после свих масовних физичких уништавања, принудних миграција, преверавања и стварања „инстант-нација“, првенствено у бившој Југославији (Stepić, 2014: 19-25).

Круна Цвијићеве синтезе били су радови о Балкану у целини, чиме је пресудно допринео да овај простор више не буде terra incognita. Његов формално антропогеографски приступ имао је веома изражене геополитичке црте - од Антропогеографских проблема Балканског полуострва из 1902. године, до капиталног двотомног дела Балканско полуострво и јужнословенске земле објављеног 1922. године (краћа верзија изашла је прво на француском језику 1918. године). И за актуелна српска наднационална интегративна опредељења важна је његова констатација већ с почетка књиге о евроазијским особинама Балканског полуострва (Cvijić, 1966: 10). Цвијић се непосредно ангажовао у оквиру српске делегације на Версајској конференцији, али је читаво своје знање и дуго стицани углед довео у питање улажући их у натегнуто и селективно примењено научно образлагање југословенског пројекта, који је био у служби геополитичких интереса победничког атлантистичког Запада. Истицао је наводну интегралност простора нове државе, заступајући чак и конструкт о једном, $a$ троименом народу!? Практично је допринео формирању њених граница - посебно оних на северу и северозападу. У том контексту, 1921. године објавио је и један од својих последњих радова (и) геополитичке садржине под насловом „Границе и склоп наше земље“. У њему није оду- стајао од концепта физичкогеографске и антропогеографске компатибилности њене територије „од Алпа до пред Егејско море“ (Cvijić, 1921: 11), мада је констатовао, можда и покајнички, да приликом разграничења „и најразборитији принципи се могу злоупотребити“ (Cvijić, 1921: 2). Потом је урадио и карту Краљевине СХС 1922. године. Окончавши свој овоземаљски живот 1927. године, стигао је да види како то његово „чедо“ представља проблематичну, нефункционалну државу, мада није доживео да буде сведок како се она за Србе претвара у монархистичку крлетку, потом ратно стратиште, па титоистичко средство обуздавања (Stepić, 2018: 297-319).

Стварање јужнословенске државе и илузија затварања српског питања утицало је инхибирајуће на српску геополитичку мисао. И у овој области наступили су парализа у самом зачетку, дуготрајан дисконтинуитет и трагично научно заостајање. Цвијићева иницијална геополитичка делатност није изнедрила следбенике, систематска истраживања, образовање стручњака, стицање квантума знања о значају „опросторења политичког“ за српски народ, те ни конституисање аутентичне српске геополитичке школе. У међуратном периоду геополитичке теме спорадично могу да се препознају најпре у оквиру правне науке, те је вредна пажање кратка, информативна студија М. Младеновића из 1934. године, актуелизована репринтом тек шест деценија касније (Mladenović, 1994).

Оптерећена „нацистичким грехом“, геополитика је и у Титовој Југославији била скрајнута и проказана. Штавише, идеологизована наука и научници имали су према њој изразито негативан став чак и деценијама после пораза нацизма, тврдећи да она „у свом политичком 
значењу представља спекулативну географско-фаталистичку теорију која је служила експанзионистичким и милитаристичким циљевима немачког Рајха и других империјалистичких држава. Она је научно погрешна јер је антиисторијска, апстрактнодетерминистичка и крајње «идеалистичка»" (Politička enciklopedija, 1975: 295). Ипак, успевала је да изађе из илегале и да се мимикријски појављује у другим наукама, нарочито у војним. У том контексту, пажње су вредни преводи дела најважнијих геополитичких и геостратегијских класика. Али, није било ни речи о некаквој српској геополитици. Тек када се на крилима МАСПОК-а и захваљујући загребачком професору Радовану Павићу она појавила у Хрватској 1970-их, као реакција васкрснула је неколико година касније и на Универзитету у Београду захваљујући иницијативи крајишког Србина професора Јована Илића. На Катедри за друштвену географију Географског факултета 1979. године уведен је предмет под „бенигним“ називом Политичка географија, али са пуно геополитичких садржаја. Било их је и на Факултету политичких наука (основан 1968. године), махом у оквиру Међународних студија, мада су се просторне димензије политичких феномена и употреба термина геополитика доследно избегавали. Изузетак је био професор Андреја Милетић, француски ђак, који је уважавао геополитику, те био међу првима који ће учествовати у њеној рехабилитацији и позиционирању у српској науци и пракси.

\section{РЕНЕСАНСА СРПСКЕ ГЕОПОЛИТИЧКЕ МИСЛИ}

(Ре)афирмација геополитике била је спора и са трагичним закашњењем, више инстинктивна него стратешки заснована. Одвијала се у изнудици слома СФРЈ и српске борбе за опстанак. Неколицина научника, високих официра, политичара, публициста и новинара из начина њеног комадања брзо је схватила да се дуго затомљено српско питање поново отвара и да није демократско, већ првенствено геополитичко. Почели су да држе јавна предавања и објављују на почетку усамљене, па све бројније и тематски разноврсније текстове. Они су представљали, с једне стране, преводе или приказе кључних радова класика геополитике, с друге стране, ауторска разматрања последица смене биполарног униполарним поретком у настајању, те с треће стране, анализе конкретних проблема разби-распадајуће земље (о деструктивности федералних јединица, неодрживости унутрашњих граница, крајишком питању, верско-грађанском рату и подели БиХ, Косову и Метохији, Рашкој области, Војводини, Превлаци...). На почетку 1990-их то су били подвизи индивидуалаца или групица посвећеника, упркос често институционализованој опструкцији и оркестрираним оптужбама за „повампирење нацистичке науке“. Тако су на Географском факултету у Београду настајале детаљне етничке карте (на нивоу насеља и на основу званичних пописних резултата) као подлога могућем разграничењу и вршена су иницијална геополитичка проучавања тока фрагментације земље. У медијској агенцији БИНА вршене су минуциозне анализе балканског уплива великих сила, њиховог антисрпског про- 
пагандног утицаја и како му парирати. Центар оружаних снага за стратегијска истраживања и студије посветио се војним аспектима југословенске кризе. У Информационом центру Српског сабора окупили су се аутори који су писали и дистрибуирали студије о географским, историјским, етничким, културним и другим својствима Срба и српског простора. У неколико београдских институција културе, најпре у Студентском културном центру и Дому културе „Студентски град“, одржавана су бројна предавања, трибине и округли столови на теоријске, глобалне, балканске, (пост)југословенске и српске геополитичке теме...

Од пресудног квалитативног значаја за заснивање аутентичне школе било је умрежавање српских геополитичких делатника. Почетно њихово окупљање било је у зборнику Тајна Балкана 1994. године, где су, поред неколико преведених студија утемељивача геополитике и савремених страних аутора, објављени важни радови домаћих стваралаца (Matić, 1994). Убрзо после тога уследио је деструктивни геополитички прелом „на терену“: пад Републике Српске Крајине, сажимање Републике Српске на дејтонско-париске територијалне габарите и све очигледније назнаке „транслирања кризе“ на косовско-метохијски део Србије. У тим егзистенцијално важним околностима 1996. године у Београду је основан Институт за геополитичке студије, који је окупио две генерације већ исказаних српских геополитички мислећих стручњака географа, политиколога, правника, економиста, дипломата, високих официра, публициста (Ч. Оцић, Ј. Илић, А. Милетић, Р. Радиновић, Ж. Панић, К. Чавошки, Д. Танасковић, М. Кнежевић, Д. Калајић, М. Степић, Д. Симић...). Плод њихове синергије било је неколико врхунских научних скупова, тематских зборника, ауторских монографија и превода: Геополитичка стварност Срба (1997), Косово и Метохија - изазови и одговори (1997), Брчко - маказе над пупчаником (1997), „Велика Албанија“ - концепт и могуће последице (1998), Геополитика хаоса (И. Рамоне, 1998), Основи доктрине одбране Републике Српске (В. Пандуревић, 1999), Геополитичка раскрића (часопис на српском и енглеском, 2000), Jугоисток Србије - континуитет кризе и могући исходи (група аутора, 2001), У вртлогу балканизације (М. Степић, 2001)...

Иако је Институт за геополитичке студије престао са радом већ 2001. године, будући да је већина његових активних истраживача одбила да „преуми“ на постпетооктобарски евроатлантистички курс, представљао је истинско проблемско, ауторско, организационо и институционално језгро за формирање српске геополитичке школе. Његови некадашњи припадници (нарочито из друге генерације), заједно са осталим и у међувремену прикљученим приврженицима геополитике (Б. Крга, М. Сакан, С. Лекић, 3. П. Пироћанац, С. Трифковић, 3. Килибарда, Љ. Деспотовић, В. Пандуревић, С. Ерић...) наставили су да интелектуално сазревају, још интензивније развијају геополитичку мисао и објављују за српску геополитику фундаментално важне радове. Међу њима, обимна монографија Геополитика - идеје, теорије, кониепиије аутора М. Степића, која се појавила 2016. године, према речима академика Ч. Оцића, једног од рецензената, јесте дело којим ce „геополитика коначно утемељује у српској науци“ (Stepić, 2016: 687). Тако је, захваљујући заједничком труду, геополитици прокрчен пут у научним институти- 
ма, универзитетској настави, политичкој и дипломатској пракси и медијском простору... Својим теоријско-концепцијским приступом, научном доследношћу, конкретним истраживањима, образовном делатношћу и популаризацијом утицали су на трећу, а крајем друге деценије 21. века и на стасавајућу четврту генерацију сада већ добро оспособљених, агилних и јавно присутних стваралаца на пољу геополитике (Д. Пророковић, Н. Вуковић, А. Гајић, С. Перишић, И. Зарић, Ж. Будимир, М. Пејковић, М. Вукашиновић...).

У вишедимензионалној активности претеча, зачетника, следбеника и неколико генерација савремених српских геополитичких мислилаца може да се идентификује „најмањи заједнички садржалац“ који их теоријски и емпиријски повезује. Из тога су проистекле кључне „тачке ослонца“, основне поставке и специфичности српске геополитичке школе (СГШ):

- Са становишта смисла „опросторења политичког“, тј. позиције (физичко)географског у бићу геополитике, СГШ није ни детерминистичка ни нихилистичка, већ посибилистичка. Сходно томе, физичкогеографске датости нити се апсолутизују, нити ниподаштавају, већ се третирају као предуслов, могућност или прилика, која ће зависно од политичких односа, војне моћи, економског нивоа и интереса бити на овај или онај начин искоришћена.

- У теоријско-концепцијском смислу, СГШ је изнуђено континенталистичка, тј. телурократска. То је резултат вишевековног потискивања Срба од мора и спречавања српске државе да реализује маритимну партиципацију, као и изразитог антисрпског деловања таласократских, атлантистичкигх сила.

- На оријентацију СГШ у великој мери утиче, а може се рећи да је и пресудно одређује, српска припадност (јужно)словенској народносној грани и религијско-цивилизацијска припадност православљу. Стога, ако се 19. век сматра веком национализма, 20. век веком идеологија, а за 21. век се предвиђа да ће бити век идентитета, српска геополитика већ има изражене идентитетске обрисе православне геополитике.

- Будући да се српски простор налази на мегакопну Евроазији, тј. на његовом ,западном полуострву“ Европи, али изван ЕУ која је под америчком контролом, СГШ би логично требало да има неоевроазијска обележја. Ипак, та оријентација још није довољно артикулисана, што не значи да су доминантне неке друге (атлантистичка, mittelerop-ска, неоосманистичка...). У овом тренутку, СГШ би најпре могла да се одреди као антиатлантистичка.

- У развојно-концептуалном смислу, СГШ још увек има одлике неокласичне (постхладноратовске, касномодерне, функционалистичке) геополитике која се тек ослобађа титоистичке и југословенске идеологизације. Она већ крупним корацима ступа у постмодерну геополитику кроз своје различите аберације, од критичке до ултрапостмодерне, мада нису ретки глобалистички, постгеополитички, нихилистички и други екскурси. 
- Проблемско поље СГШ налази се углавном у оквиру геополитике постпростора, тј. обухвата сложена и вишедимензионална питања постјугословенског дела Балкана. Истраживања глобалних, евроазијских, постсовјетских и европских процеса потребна су и постоје, али су првенствено у контексту њихове пројекције на балкански регион као „вериге света“, „геополитички чвор“, „процеп светова““... Иако се не оспорава да је садашњи Балкан под атлантистичком контролом, СГШ већ антиципира његово постатлантистичко преуређење и могуће реуспостављање интересних сфера, са посебним нагласком на нову чињеницу - уплив Кине и њено утицајно „наткривање“ (Stepić, 2017: 9-37). Бројна и драгоцена су мезо и микрорегионална истраживања унутар балканског простора - о великоалбанским и великохрватским аспирацијама, геополитичким димензијама „балканске миграционе руте“, просторним аспектима исламистичког екстремизма...

- СГШ има интегралистичка својства јер у фокусу има не само Србију, већ српске земље у целини. Тиме она чини крупан искорак - критички се односи према идеолошким, титоистичким границама као вештачким, наметнутим и антисрпским, за разлику од домаће и међународне политике и дипломатије које су и даље таоци ABНOJских „принципа“. Српски простор у целини исправно се перцепира као пресудно важан Heartland Балкана који представља кључну карику унутар евроазијског Rimland-a, али и све више контактну зону са глобалним „Исламским Heartland-ом“.

- СГШ потенцира да је српско питање у највећој мери геополитичко питање и првенствено на тај начин мора да се решава. Уосталом, оно се тако третира у концепцијским приступима и практичном деловању великих сила током „процеса дугог трајања“. СГШ не оспорава да је српско питање свеобухватно - и верско, демографско, историјско, културно, лингвистичко, демократско, етичко, економско, развојно... Стога не би требало да му се приступа парцијално, већ што целовитије.

- У погледу временског оквира проучавања, СГШ махом је окренута новоисторијским и рецентним геополитичким феноменима. $\mathrm{y}$ неким случајевима то имплицира идеолошка застрањивања, полит-конјунктурност, дескриптивност и статичност, а некада улазак у „научни контраритам“, па чак и скретање на странпутицу дневнополитичког ,аналитичарења“. С друге стране, појављују се радови из домена прогностичке и сценаристичке геополитике, који се крећу у координатама од јефтиног сензационализма до квалитетних, аргументованих, луцидних, иновативних и практично употребљивих процена.

- Са становишта просторног обухвата, СГШ је највише посвећена ендогеополитичким и (мезо)регионалним геополитичким питањима, док је у погледу суштине геополитике сасвим мало оријентисана на теоријско-методолошка истраживања. Апликативна страна геополитике 
такође је недовољно заступљена, будући да су српски професионални политичари и дипломате неадекватно географски образовани и углавном виртуелно профилисани, а војно-безбедносни, економски, саобраћајни, просторно-планерски и други стратези оријентисани више у складу са наднационалним него са „српским становиштем“. Али, зато постоји прави „цунами“ псеудогеополитичких урадака и популарне геополитизације свега постојећег, који прете да искомпромитују не само СГШ у настанку, већ (поново) и тек ревитализовану научну геополитику.

- Кључна системско-структурна (гранска) обележја СГШ јесу: локацијско-геополитичка (положај Балкана, Србије и српских земаља, конкретних области, мора и приобаља...), ресурсно-геополитичка (контрола резерви угља, плодног земљишта, воде, обојених и ретких метала...), демогеополитичка (махом балкански етнопросторни односи и интереси), лимо-геополитичка (проблем ,неадекватних граница“ бивших југо-република и конкретни гранични проблеми), економско-геополитичка (размештај привреде, просторна усмереност страних инвестиција, друмско-железнички и посебно гасоводни коридори...) и цивилизацијско-геополитичка (конфликтност контакта православног, римокатоличког и исламског ареала).

- Интензиван развој српске научне геополитике у протеклих тридесетак година заснивао се на универзалном појмовно-категоријалном апарату класичне и делимично постмодерне геополитичке мисли. Али, у специфичним условима слома Југославије и редефинисања постјугословенског простора, временом се формирала карактеристична српска геополитичка терминологија, богата неологизмима који на адекватан начин дефинишу појаве и процесе током „нове балканизације“ (балкански геополитички чвор, балкански геополитички лук, балканиде, балканска макротврђава, разби-распад СФРЈ, етноинжењеринг, декрет-нације, гораждански panhandle...).

\section{ЗАКљУЧАК}

„Развојни пут геополитике био је компликован, тешко проходан, са многим успонима и падовима, скретањима на беспућа идеолошке злоупотребе и успонима на пиједестал супернауке“ (Stepić, 2019: 83). Прошавши кроз пет и улазећи у шесту еволутивну фазу, „она је већ свукла ,тесну кожу' научне дисциплине или субдисциплине и постала посебна, истина контактна и прожимајућа - наука“ (Stepić, 2017: 21). И српска спознаја значаја међузависности просторног и политичког има дубоке емпиријске корене, а као артикулисана научна мисао зачела се у условима борбе за ослобођење и уједињење током прве две деценије 20. века После вишедеценијског дисконтинуитета, геополитика међу Србима доживљава ренесансу поново као рефлекс - у овом случају на слом југословенске државе и фрагментацију српских земаља крајем 20. века. Будући да у правом научном смислу траје тек непуних тридесетак година, морала је да убрзано пређе 
пут од егзистенцијалне националне потребе, интуитивног реаговања појединаца и мукотрпног доказивања пред сумњичавом јавношћу, до садашњег (одоцнелог) уважавања, стицања како-тако сигурне позиције у групацији друштвених наука и систематичних проучавања махом оријентисаних на српску позицију на Балкану. У таквим условима постављени су темељи српске геополитичке школе.

Српска геополитичка школа заснива се на светској геополитичкој баштини, али своју посебност гради на националном научном и историјском, верском, културном, географском, политичком, војном и другом наслеђу. Данас је она усмерена махом на изучавање утицаја преобликовања светског поретка од униполаризма ка мултиполаризму на промене у балканским, посебно постјугословенским односима. Сходно томе, већ неколико генерација геополитичких делатника бави се поново отвореним српским питањем у веома неповољним међународним околностима, које подразумевају експанзију Запада према истоку, његово настојање да потпуно овлада Балканом и обрачун са српским чиниоцем „учитаним“ за традиционалног експонента Русије. Главне тематске изазове представљају (пре) вредновање положаја Србије и осталих српских земаља, фрагментација и сажимање српског простора, геополитичке последице идентитетских трансформација, отворена или потенцијална питања као што су разлози пада Републике Српске Крајине, угроженост Републике Српске, сепаратизам на Косову и Метохији, тензије у Рашкој области, конкретне претензије суседа, погранични проблеми...

У савременој српској друштвеној науци већ постоји групација талентованих, проницљивих, оригиналних, теоријско-мето- долошки припремљених, интелектуално одважних и компетентних аутора који својим карактеристичним приступом чине изгледном перспективу српске геополитичке школе. Да би се она учврстила и напредовала неопходно је подићи нове генерације на већ постојећим научним темељима. Стога би геополитику, као општу, регионалну и гранску, требало одговорније увести у универзитетску наставу, обезбедити јој достојно место у делатности института (штавише, у специјализованим), посветити већу пажњу континуираним геополитичким истраживањима српског популационо-просторног елемента, његовог непосредног суседства и значаја Балкана у целини. У образовно-научном смислу геополитика је још увек недовољно, парцијално и често неадекватно заступљена. Мало је има на географским и политиколошким факултетима, тамо где би требало да буде један од кључних предмета (позитиван изузетак је бањалучки Факултет политичких наука). Потпуно је искључена из студија философије, социологије, историје, теологије, права, економије, саобраћаја..., а спорадично се појављује на војно-безбедносним, културолошким, медијским и дипломатским високошколским институцијама. Атрактивна је постала („лепо звучи“) за намножене приватне универзитете, али је често предају некомпетентни наставници. Они су обично „вршиоци дужности“ факултетских предавача, који само „покривају предмете“ псеудогеополитичког, геоекономског, стратегијског, менаџментског и сличног профила, уведене захваљујући болоњизацији домаћег високог образовања. Управо конјунктура геополитике изазвала је појаву посебне врсте веома опасног „кукоља“ - бројне надригеополитичаре, геополи- 
тичаре-аматере, геополитичке заљубљенике, аналитичаре, сензационалисте, ексклузивисте и партијске пропагандисте. Како би рекао владика Николај, они су ненаучени већ постали учитељи другима. Својом нестручношћу, површношћу и естрадним приступом од геополитике праве „и све и ништа“, претећи да је поново искомпромитују.

\section{REFERENCE}

Budimir, Ž. (2012). Makroregionalno geopolitičko strukturisanje sveta: aktuelnost Makinderove Hartlend koncepcije. Nacionalni interes, br. 2: 223-246.

Despotović, LJ. (2019), Geopolitika svetosavlja - srpsko nacionalno pitanje $\mathrm{u}$ istorijskom rasponu od krštene do prirodne Srbije. Sremski Karlovci: Kairos.

Dinaricus /Cvijić J./ (1915). Skica dinarskih južnoslovenskih zemalja. u: Jedinstvo Jugoslovena, Niš: Državna štamparija Kraljevine Srbije.

Dugin, A. (2004). Osnovi geopolitike. knjiga 1. Zrenjanin: Ekopres.

Živković, D. (2012). Srpska kartografija - od inženjerske do digitalne. Glasnik Srpskog geografskog društva, № 3: 1-10.

Kjellén, R. (1899). Stu $\neg$ dier öfver Sveriges politiska gränser. Ymer, Vol. 3: 283-331.
Đorđević, J. /ur./ (1975). Politička enciklopedija. Beograd: Savremena administracija.

Stanković, M. S. (2012). Stogodišnjica Srpskog geografskog društva (1910-2010). u: Predrag Manojlović (ur.). Spomenica o stogodišnjici Srpskog geografskog društva, Posebna izdanja, knj. 72 (str. 3-66). Beograd: Srpsko geografsko društvo.

Stepić, M. (2004). Srpsko pitanje geopolitičko pitanje. Beograd: Jantar grupa.

Stepić, M. (2014). Vek posle Cvijića: etno-civilizacijska karta Balkana i njene geopolitičke posledice. (str. 19-25), u: Grčić, M., Dejan Filipović, D., Slavoljub Dragićević, S: (ur.). Geografsko obrazovanje, nauka i praksa: razvoj, stanje, perspektive (str. 19-25). Beograd: Geografski fakultet Univerziteta u Beogradu.

Stepić, M. (2016). Geopolitika - ideje, teorije, koncepcije. Beograd: Institut za političke studije.

Stepić, M. (2017). Deatlantizacijom do stabilizacije Balkana: srpski nacionalni interes. Nacionalni interes, br. 1: 9-37.

Stepić, M. (2017). Od (neo)klasičnih ka postmodernim geopolitičkim postulatima. u: Milomir Stepić (ur.) Svet i nove geopolitičke paradigme (str. 13-36). Beograd: Institut za političke studije.

Stepić, M. (2018). Geopolitički smisao jugoslovenstva i jugoslovenske države. u: Nikola Marinković (ur.). Istorija jedne utopije - 100 godina od stvaranja Jugoslavije. knjiga 2 (str. 297-319). Beograd: Catena mundi.

Mladenović, M. (1994). Šta je geopolitika? 
Stepić, M. (2019). Geopolitika: od geografske i politikološke discipline do samostalne nauke. Srpska politička misao, br. 1: 75-96.

Mackinder, J. H. (1904). The Geographical Pivot of History. Geographical Journal, Vol. 23, № 4: 421-443.

Cvijic, J. (1918). Etnographic Map of the Balkan Peninsula. The Geographical Review, Vol. V, № 5.

Cvijić, J. (1921). Granice i sklop naše zemlje. Glasnik Geografskog društva, № 5: str. 1-17.

Cvijić, J. (1966). Balkansko poluostrvo i južnoslovenske zemlje. Beograd: Zavod za izdavanje udžbenika SR Srbije.

Cvijić, J. (1969). Opšta geografija antropogeografija. Beograd: Zavod za udžbenike SR Srbije.

Cvijić, J. (1987). Govori i članci. Sabrana dela, knjiga 3 (tom 1), Beograd: Književne novine; Zavod za udžbenike i nastavna sredstva.

Cvijić, J. (2000). Govori i članci. Sabrana dela, knjiga 3 (tom 1), Beograd: SANU; Zavod za udžbenike i nastavna sredstva. 
Milomir Stepić

Review Paper

Željko Budimir

\section{THE FOUNDATION OF THE SERBIAN SCHOOL OF GEOPOLITICS}

Keywords:

Cvijic's anthropogeography;

Serbian question;

posibilism; telurocracy;

multidisciplinarity; geopolitics.

Authors:

Dr. Milomir Stepić is a Full professor and the Research Fellow of the Institute of Political Studies in Belgrade.

Željko Budimir, MA is a

Senior teaching assistant of the Faculty of Political Sciences of the University of Banja Luka.

Correspondence:

milomir.stepic@gmail.com

zeljko.budimir@fpn.unibl.org

Field:

Geopolitics

DOI:

10.5937/politeia0-22110

Paper received on:

11.04.2019.

Paper accepted for publis-

hing on:

22.05.2019

\section{Summary}

Practical geopolitics has long since existed in Serbian tradition; however, it has not developed enough in the scientific sense. The true beginnings of Serbian geopolitical thought can be found in the anthropogeographical works of Jovan Cvijic during the first decades of the 20th century, and his engagement in the formation of the South Slavic state. Afterwards, there is a long discontinuity, especially noticeable after the Second World War due to the Nazi misuse of geopolitics. The renaissance and the true development of Serbian geopolitics happens because of existential national causes - when the Serb issue is opened again, during the disintegration of Yugoslavia and in unfavorable international circumstances. Since then, four generations of geopolitical experts have matured, in whose research there is a specific common scientific approach, and one can conclude that an authentic Serbian geopolitical school is emerging. Its basic characteristics are that it is possibilistic, telurocratic, integralist, regionalist (Balkanic), and multidisciplinary, and that it has established its own terminology, alongside the universal one. Further progress of the Serbian geopolitical school will depend on the respect it garners in political-diplomatic practice, its position in the educational-scientific system, on adequate media promotions and successful suppression of trivialisation. 
